\title{
СІМЕЙНО-ОРІЄНТОВАНА МЕДИЦИНА ЯК ВАЖЛИВИЙ НАПРЯМ РОЗВИТКУ ПЕДІАТРИЧНОЇ ДОПОМОГИ В УКРАЇНІ
}

\author{
Т. Д. Зозуля ${ }^{1}$, Н. Б. Галіяш ${ }^{2}$, Л. М. Ковальчук ${ }^{1}$, А. Г. Каднічанський ${ }^{1}$ \\ ${ }^{1}$ Самбірський медичний коледж \\ ${ }^{2}$ Тернопільський національний медичний університет \\ імені І. Я. Горбачевського МОЗ Украӥни
}

\begin{abstract}
У статті проаналізовано досвід впровадження сімейно-орієнтованого догляду в медичних закладах країн Північної Америки та Західної Європи. Показано, що застосування цього підходу може мати позитивні наслідки як для дітей та їхніх сімей, так і сприяти покращенню ефективності роботи медичних кадрів та економічної ефективності медичних послуг.
\end{abstract}

\section{FAMILY-ORIENTED MEDICINE AS AN IMPORTANT DIRECTION OF IMPROVING PEDIATRIC HEALTH CARE IN UKRAINE}

\author{
T. D. Zozulia ${ }^{1}$, N. B. Haliyash ${ }^{2}$, L. M. Kovalchuk ${ }^{1}$, A. G. Kadnichansky ${ }^{1}$ \\ ${ }^{1}$ Sambir Medical College \\ ${ }^{2}$ I. Horbachevsky Ternopil National Medical University
}

\begin{abstract}
The article analyzes the experience of implementing family-oriented care in healthcare facilities in North America and Western Europe. It has been shown that the application of this approach can have positive outcomes for both children and their families, and can contribute to improving the efficiency of medical staff and the cost-effectiveness of medical services.
\end{abstract}

Вступ. Усі медичні працівники визнають, що якісну медичну допомогу дітям повинні надавати за участю членів сім'ї. Адже, активне залучення батьків у процес догляду за дитиною, навіть в умовах стаціонару, значно покращує ії фізичне та психосоціальне здоров'я, прискорює одужання та збільшує задоволеність медичними послугами.

Багато медичних працівників активно підтримують ідею догляду за дитиною з урахуванням потреб сім'ї, проте практично такий підхід не був повністю реалізований в українських лікувально-профілактичних закладах. Питання щодо невідповідності між потребою в підтримці сімей та наявною практикою можна частково вирішити шляхом впровадження сімейно-орієнтованого підходу в наданні медичної допомоги (розширення прав та можливостей сімей на противагу класичному медичному підходу). Крім того, фахівці часто навмисно заохочують сімейну залежність, відчуження та безпорадність, беручи контроль та призначаючи допомогу без урахування потреб сім'ї задля зручності персоналу та вигоди для медичного закладу.

Термін «сімейно-орієнтований догляд» описує практичний підхід, який визнає центральну роль сім'іу житті дитини та передбачає активне залучення членів сім'ї до участі в діагностично-лікувальному процесі. Даний підхід сформувався у відповідь на критичну потребу підтримувати взаємозв'язок між госпіталізованими дітьми та їхніми сім'ями, оскільки у минулому ці відносини нехтувалися через примусове відокремлення дитини під час госпіталізації [1]. Його широко впроваджують у лікувально-профілактичних закладах країн Північної Америки та Західної Європи. На жаль, в Україні лише поодинокі лікарні демонструють бажання системно включати сім'ю у догляд за маленькими пацієнтами та робити атмосферу в медзакладі більш комфортною для дітей. Тому метою даної роботи було з'ясування особливостей та переваг сімейно-орієнтованого догляду для педіатричної практики на основі вивчення досвіду інших країн.

( Т. Д. Зозуля, Н. Б. Галіяш, Л. М. Ковальчук, А. Г. Каднічанський, 2020 
Основна частина. Сімейно-орієнтований догляд - це інноваційний підхід до планування, надання та оцінки медичної допомоги, який ґрунтується на взаємовигідному партнерстві між пацієнтами, їхніми сім'ями і надавачами медичних послуг та визнає важливість родини у житті пацієнта [2, 3].

Основні постулати сімейно-орієнтованого догляду, задекларовані Асоціацією з охорони здоров'я дітей (Association for the Care of Children's Health (ACCH)) y 1987 р., ґрунтуються на тому, що першорядне значення має задоволення мінливих потреб усіх членів сім'ї, а не тільки дитячих, і включає вісім рівноважливих елементів [4].

\section{Ключові елементи сімейно-орієнтованого догляду:}

1. Визнання закладами охорони здоров'я того факту, що сім'я є важливим контекстом життя дитини, що передбачає зміни системи медичного обслуговування та ролі медичного персоналу.

2. Впровадження сімейно-орієнтованого підходу на всіх рівнях: як у лікувально-профілактичних закладах, так і на рівні громади та, власне, сім'і, що включатиме як індивідуальний догляд за дітьми, так і розробку, впровадження та оцінювання програмних заходів, які 6 сприяли його дієвій імплементації на всіх рівнях системи охорони здоров'я.

3. Обмін повною та неупередженою інформацією між сім'ями та медичними працівниками.

4. Формування політики та практики закладів охорони здоров'я на засадах визнання і поваги до культурного, етнічного, расового, духовного, соціального, економічного, освітнього та географічного різноманіття.

5. Запровадження комплексної політики та програм з урахуванням різних методів взаємодії з родинами, що забезпечували б розвиток, навчання, емоційну, соціальну та фінансову підтримку для задоволення різноманітних потреб сімей.

6. Заохочення взаємопідтримки між родинами 3 подібними проблемами та створення відповідних громадських чи родинних організацій та соціальних мереж.

7. Забезпечення того, щоб система охорони здоров'я та системи підтримки в суспільстві, лікувально-профілактичних закладах та будинках для дітей, які потребують спеціалізованої медичної допомоги, були гнучкими, доступними та всебічними у відповідь на різноманітні сімейні потреби.
8. Оцінюючи дітей та їхні сім'ї, необхідно визнавати, що вони володіють широким спектром як сильних, так і слабких сторін, емоцій та прагнень, окрім потреби у спеціалізованих службах та медико-соціальній підтримці.

Елементи сімейно-орієнтованого догляду ґрунтуються на принципах, мета яких сприяти більшому сімейному самовизначенню, здатності до прийняття рішень, самоконтролю та самореалізації. Загалом такий підхід забезпечує розширення прав і можливостей сім'ї. На відміну від цього, медична модель спрямовує фахівців охорони здоров'я на роль контролера лікувальних втручань. Такий підхід призводить до залежності дитини та членів сім'ї від постачальників медичних послуг. Ця позиція знаходиться в прямому протиріччі з умовами, необхідними для більш активного залучення сімей та опікунів для догляду за дітьми з порушенням здоров'я.

Необхідно зазначити, що роль педіатрів та медичних сестер у впровадженні сімейно-орієнтованого догляду є вкрай важливою, адже діти є більш залежні від підтримки сім'ї. Вони визнають, що емоційна, соціальна підтримка та забезпечення розвитку $\epsilon$ невід'ємними компонентами надання медичної допомоги дітям, а також поважають сильні сторони та культурні цінності кожної дитини та їхніх родин і розглядають досвід перебування у закладах охорони здоров'я як можливість підтримувати та розвивати сім'і у догляді та прийнятті медичних рішень.

Вивчаючи результати впровадження сімейноорієнтованого догляду в практику лікувально-профілактичних закладів інших країн, виявлено, що позитивні зміни стосуються кількох аспектів, які визначають якість надання медичної допомоги.

Насамперед запровадження сімейно-орієнтованого підходу на рівні первинної ланки медичної допомоги приводить до значного скорочення кількості відвідувань відділень невідкладної допомоги у педіатричній практиці [5]. Дослідження, проведені у дитячій лікарні Бостона, підтверджують, що присутність одного з батьків під час лікувальних процедур зменшує тривожність дитини та підвищує рівень задоволення батьків наданою допомогою [6]. Діти після тонзилектомії, чиї матері активно брали участь у догляді за ними в післяопераційний період, одужували швидше і були виписані раніше, ніж діти, матері яких не були активно задіяні [4]. Ряд дослідників, які оцінювали поліпшення якості надання медичної допомоги, виявили, що діти, які перенесли операцію, плакали 
менше, були менш неспокійними та потребували менше ліків, коли їхні батьки допомагали з оцінкою болю та були присутніми при лікуванні. Чітка комунікація між лікарями, пацієнтами та батьками приводить до покращення задоволеності наданою допомогою у стаціонарних педіатричних відділеннях та відділеннях інтенсивної терапії новонароджених [7]. При такому підході до організації догляду пацієнти також демонстрували підвищену компетентність і впевненість у догляді за немовлятами на момент виписування та висловлювали готовність звертатися за допомогою до медичних працівників цієї лікарні [8]. Також $\epsilon$ підтвердження, що коли батьки належним чином підготовлені, вони не перешкоджають проведенню процедури, а навіть полегшують її проведення як для дитини, так і для медпрацівників [9].

Починаючи з 1993 р., допомога, орієнтована на сім'ю, була стратегічним пріоритетом однієї з дитячих лікарень Медичного коледжу Джорджії, США. Члени сімей брали участь у плануванні проекту нової лікарні, вони були залучені у процес навчання персоналу та роботу інших ключових лікарняних комітетів та робочих груп. Протягом останніх років ця дитяча лікарня постійно отримувала найвищі показники задоволеності пацієнтів та їхніх сімей у загальнонаціональному опитуванні серед педіатричних медичних закладів. Крім того, тут відзначено скорочення тривалості перебування пацієнта в лікарні, зменшення кількості лікарських помилок та покращення задоволеності медичного персоналу [10,11].

У проекті «Медичний будинок», який фінансувався федеральним бюджетом, для впровадження оновленої моделі покращення якості надання медичних послуг дітям з особливими потребами, сім'ї, які обслуговувалися 13 центрами первинної педіатричної допомоги, співпрацювали з педіатрами та іншими медпрацівниками, щоб розширити спектр послуг та зробити їх більш чутливими до пріоритетів та потреб цих дітей та їхніх родин. Ці центри постійно інтегрували сімейні рекомендації у планування своєї діяльності та розробки протоколів догляду, внаслідок чого продемонстрували поліпшення на 34 \% за стандартизованою шкалою оцінювання послуг медичних будинків [12].

Безперечно, серед важливих позитивних наслідків впровадження сімейно-орієнтованого догляду $\epsilon$ підвищення задоволення власне медичних працівників своєю працею. За дослідженням R. Heller та D. McKlindon (1996), співробітники дитячої лікарні, які брали участь у навчальних програмах для сімей у ролі вчителів, вважали цей досвід дуже цінним [13]. Коли допомога, орієнтована на сім'ю, є наріжним каменем у дитячому відділенні невідкладної допомоги, співробітники мають більше позитивних почуттів щодо своєї роботи. Це приводить до покращення ефективності роботи та меншої плинності кадрів [14].

Не менш важливими є дослідження, які показують, що впровадження сімейно-орієнтованого догляду покращує також економічну ефективність медичних послуг. Так, у дитячій лікарні, де реорганізовано догляд за пацієнтами з орієнтацією на родини шляхом створення цілодобового відкритого відвідування сімей та поліпшення комунікації і обміну інформацією, спостерігали зменшення тривалості перебування у лікарні на 30-50 \%. Інші результати включали меншу кількість повторних госпіталізацій, зменшення звернень у відділення невідкладної допомоги, що знизило витрати на охорону здоров'я та потребу в додаткових послугах [15]. Література з управління ризиками вказує на те, що пацієнти та сім'ї значно рідше ініціюють судові процеси, навіть якщо були допущені помилки, якщо $є$ відкрите та ефективне спілкування та довірчі стосунки між практикуючим лікарем та родиною пацієнта [16].

В Україні у грудні 2019 р. за підтримки Фундації «Дім Рональда МакДональда» та Міністерства охорони здоров'я України була проведена 3-тя Конференція з сімейно-орієнтованої медицини, метою якої було поширити знання про цей підхід серед українських медиків. Ця Фундація активно підтримує розвиток даного напряму, зокрема, ініціює відкриття сімейних кімнат у лікарнях - місця, де зможуть перебувати батьки, аби завжди бути поруч із дитиною $[17,18]$.

щоб полегшити впровадження сімейно-орієнтованого догляду, медичні працівники повинні шукати інформацію про сім'ю; включати цю інформацію в план догляду, навчити сім'ю відповідним елементам медичного догляду. Здобуваючи кращі знання та володіючи повною інформацією, батьки (опікуни) та інші члени родини можуть брати участь у догляді за дитиною. Серед інших стратегій, що сприяють сімейно-орієнтованому догляду, є: відсутність обмежень для відвідувачів за віком чи кількістю (якщо родина не визначила інше); адекватні спальні місця для батьків (опікунів) у дитячих палатах; харчування або знижки в кафетеріях для них, безкоштовна автостоянка, участь членів сім'ї у міждисциплінарних обходах щодо догляду за дитиною тощо. 
Втім існує низка чинників, які перешкоджають впровадженню сімейно-орієнтованого догляду. Серед них недостатнє розуміння як принципів даного підходу, так і неоднозначність щодо конкретних дій у рамках сімейно-орієнтованої медицини як з боку закладу, так і з боку пацієнта. Окремі установи вважають, що запровадження сімейно-орієнтованого підходу делегує сім'ям більше відповідальності, ніж вони того бажають і можуть на себе взяти. Члени родин також можуть не достатньо розуміти, що вони можуть і мають очікувати від партнерства.

Перешкодою $є$ також недостатня підтримка діяльності закладів, які бажають застосовувати сімейноорієнтований догляд. Це включає як недостатнє фінансування власне лікувально-профілактичних закладів, відсутність компенсацій для лікаря, який витрачає час і зусилля, необхідні для налагодження партнерства, так і скрутне фінансове становище сім'і та безробіття.

Відсутність адекватних досліджень, які 6 якісно оцінювали враження сім'ї від обслуговування та об'єктивно продемонстрували кореляції між конкретними заходами та загальним клінічним станом і результатами, теж не сприяє інтенсивному впровадженню сімейно-орієнтованої медицини. Проведення якісних досліджень ускладнюється відсутністю добре валідованих критеріїв оцінки результатів такого

\section{СПИСОК ЛІТЕРАТУРИ}

1. Галіяш Н. Комунікативні навички в медицині : посіб. / Наталія Галіяш, Наталія Петренко, Наталія Бількевич. - Тернопіль : ТДМУ, 2019. - 132 с.

2. Сімейно орієнтована медицина: сучасний стан і майбутні напрями педіатричної допомоги / Д. З. Куо, Е. Дж. Хутроу, П. Аранго і співавт. // Медична газета «Здоров'я України 21 сторіччя». - 2018. - № 7 (428).

3. Patient- and family-centered care and the pediatrician's role / Committee on Hospital Care and Institute for Patient- and Family-Centered Care // Pediatrics. - 2012. Vol. 129, Issue 2. - P. 394-404. - DOI: https://doi.org/10.1542/ peds.2011-3084

4. Shelton T. L. Family-centered care for children needing specialized health and developmental services / T. L. Shelton, J. S. Stepanek. - Bethesda, MD: Association for the Care of Children's Health, 1994.

5. Quality of primary care and subsequent pediatric emergency department utilization / D. C. Brousseau, R. G. Hoffmann, A. B. Nattinger [et al.] // Pediatrics. - 2007. No. 119 (6). - P. 1131-1138. обслуговування. Шкала вимірювань процесів обслуговування, розроблена в 90-х роках, оцінює сімейну орієнтованість обслуговування, її переважно використовують для дітей з порушеннями розвитку нервової системи $[2,19]$.

Висновки. Оскільки реформа системи охорони здоров'я в Україні вимагатиме все більшої конкурентності між закладами, що надають медичні послуги, впровадження сімейно-орієнтованого догляду, як це показує досвід інших країн, може мати позитивні наслідки як у плані підвищення задоволеності пацієнтів та членів їхніх родин, так і покращення ефективності роботи кадрів та економічної ефективності медичних послуг. Таким чином, необхідно поширювати досвід застосування принципів сімейно-орієнтованого догляду серед медичних працівників, розробляти чіткі рекомендації щодо їх впровадження, а також включати як обов'язковий елемент у стандарти надання педіатричної медичної допомоги. Необхідно пропонувати збільшення зовнішніх ресурсів для реформи обслуговування та системних змін, особливо таких, що стосуються сімейно-орієнтованої медицини. Постійне навчання членів законодавчих органів, осіб, які визначають політику, та фондових агентств має посилити усвідомлення коротко- і довготривалого значення впровадження сімейно-орієнтованого догляду в системі охорони здоров'я.

6. LaRosa-Nash P. A. An approach to pediatric perioperative care. Parent-present induction / P. A. LaRosa-Nash, J. M. Murphy // Nurs. Clin. North. Am. - 1997. - No. 32 (1). P. 183-199.

7. Ammentorp J. Parents' priorities and satisfaction with acute pediatric care / J. Ammentorp, J. Mainz, S. Sabroe // Arch. Pediatr. Adolesc. Med. - 2005. - No. 159 (2). P. 127-131.

8. Griffin T. Transition to home from the newborn intensive care unit: applying the principles of family-centered care to the discharge process / T. Griffin, M. Abraham // J. Perinat. Neonatal Nurs. - 2006. - No. 20 (3). - P. 243-249.

9. Wolfram R. W. Effects of parental presence during children's venipuncture / R. W. Wolfram, E. D. Turner // Acad. Emerg. Med. - 1996. - No. 3 (1). - P. 58-64.

10. Sodomka P. Patient- and family-centered care / Patricia Sodomka // The Patient- and Family Centered Care: Good Values, Good Business Conference; American College of Healthcare Executives Conference; May 17-18, 2001. Virginia Beach, VA. 
11. Hobbs S. F. Developing partnerships among patients, families, and staff at the Medical College of Georgia Hospital and Clinics / Sandra F.H obbs, Patricia F.Sodomka // The Joint Commission Journal on Quality Improvement. - 2000. Volume 26, Issue 5. - P. 268-276.

12. Cooley W.C., McAllister J.W. Building medical homes: improvement strategies in primary care for children with special health care needs. / W.C.Cooley, J.W.McAllister // Pediatrics. - 2004. - No. 113 (suppl 5). - P. 1499-1506.

13. Heller R., McKlindon D. Families as "faculty": parents educating caregivers about family-centered care / R. Heller, D. McKlindon // Pediatr Nurs. - 1996. - Volume 22, Issue 5. P. 428-431.

14. Hemmelgarn A. L. Emergency room culture and the emotional support component of family-centered care / A. L. Hemmelgarn, D. Dukes // Child Health Care. - 2001. No. 30 (2) . - P. 93-110.
15. Forsythe P. New practices in the transitional care center improve outcomes for babies and their families / P. Forsythe //J. Perinatol. - 1998. - No. 18 (6 pt 2 Suppl). - P. 13-17.

16. Johnson B. Collaborating with patients and their families. / B. Johnson, D. Ford, M. Abraham // J. Health Risk Manag. - 2010. - No. 29 (4). - P. 15-21.

17. Беловльченко Г. Чому лікарі виступають «за» участь родини у лікуванні дитини [Електронний ресурс] / Г. Беловльченко. - Режим доступу : https://dyvys. info/2017/11/10/chomu-likari-vystupayut-za-uchast-rodynyu-likuvanni-dytyny/ (дата звернення 26.02.2020). - Назва з екрана.

18. Що таке сімейно-орієнтована медицина? [Електронний ресурс]. - Режим доступу : https://rmhc.org.ua/ vazhlivo-buti-poruch/ (дата звернення 26.03.2020). - Назва з екрана.

19. Arango P. Family-centered care / Polly Arango // Academic Pediatrics. - 2011. - No. 11. - P. 97-99.

Отримано 02.04.20 